\title{
SPATIOTEMPORAL DYNAMICS OF AMMONIA NITROGEN AND ITS RESPONSE TO INFLOW RIVER BASED ON RANDOM FOREST MODEL IN NORTHWEST TAIHU LAKE, CHINA
}

\author{
XU, C. ${ }^{1,2}-$ YANG, G. S. ${ }^{1,2^{*}}-$ WAN, R. R. ${ }^{1,2^{*}}-$ LI, B. ${ }^{1,2}-$ MA, Q. ${ }^{3}-$ LU, X. M. ${ }^{3}-$ LV, W. ${ }^{4}$ \\ ${ }^{I}$ Key Laboratory of Watershed Geographic Sciences, Nanjing Institute of Geography and \\ Limnology, Chinese Academy of Sciences, Nanjing 210008, P.R. China \\ ${ }^{2}$ University of Chinese Academy of Sciences, Beijing 100049, P.R. China \\ ${ }^{3}$ Jiangsu Province Hydrology and Water Resources Investigation Bureau \\ Nanjing 210029, P.R. China \\ ${ }^{4}$ Suzhou Substation of Jiangsu Province Hydrology and Water Resources Investigation Bureau \\ Suzhou 215006, P.R. China \\ ${ }^{*}$ Corresponding authors \\ e-mail: gsyang@niglas.ac.cn (Yang, G. S.),rrwan@126.com (Wan, R.R.) \\ (Received 11 ${ }^{\text {th }}$ Jan 2019; accepted $8^{\text {th }}$ Mar 2019)
}

\begin{abstract}
Inflow rivers have crucial impact on lake eutrophication. Ammonia nitrogen $\left(\mathrm{NH}_{4}{ }^{+}-\mathrm{N}\right)$ in inflow rivers have tightly coupled relationships with water quality in Lake Taihu, China. Based on the monthly concentrations from 2009 to 2015, this study focused on the spatiotemporal dynamics of $\mathrm{NH}_{4}{ }^{+}-$ $\mathrm{N}$ in northwest Taihu Lake and utilised random forest (RF) model to simulate its response to inflow rivers. Results indicated that (1) in northwest Lake Taihu, the spatiotemporal distribution patterns of $\mathrm{NH}_{4}{ }^{+}-\mathrm{N}$ concentrations are distinct, and river inputs were the major source of $\mathrm{NH}_{4}{ }^{+}-\mathrm{N}$ loadings. (2) Scenario simulation results in RF models indicated that the inflow loads should be controlled under $6427.38,3248.01,2206.92$ and $1107.58 \mathrm{ta}^{-1}$ for the protective targets. (3) In $2015, \mathrm{NH}_{4}{ }^{+}-\mathrm{N}$ concentrations in four lake regions and $\mathrm{NH}_{4}{ }^{+}-\mathrm{N}$ loads from inflow rivers were consistent with the simulation results in $\mathrm{RF}$ models. The $\mathrm{NH}_{4}{ }^{+}-\mathrm{N}$ concentrations decreased approximately $6 \%, 34 \%, 44.44 \%$ and $6.67 \%$ in North Zone and Zhushan, Meiliang and Gonghu Bays, respectively, despite reduction in external $\mathrm{NH}_{4}{ }^{+}-\mathrm{N}$ loads by $8.99 \%, 11.41 \%, 51.38 \%$ and $62.87 \%$. This study provides further understand on quantifying the reduction of nutrient loading from inflow rivers and governing Lake Taihu or other typical eutrophic lakes.
\end{abstract}

Keywords: eutrophication, inflow river, load reduction, $\mathrm{NH}_{4}{ }^{+}-\mathrm{N}$, Taihu Lake, water quality

\section{Introduction}

With urbanisation development and population expansion, a large number of ecologically important freshwater bodies have experienced harmful water quality degradation and algal blooms, which have been a national concern in the recent decades (Schindler and Hecky, 2009; Qin et al., 2015; Wu et al., 2016). Previous research suggests that lake eutrophication is driven by physical, chemical and biological parameters and land use influences, including sediment dredging, aquatic organisms and hydrodynamic conditions (Wang et al., 2011; Bian et al., 2016). A great amount of nutrients and other contaminants enter lakes from river inputs, which are the main pollution route among all the influencing factors and considerably affecting the aquatic environment and ecosystem heath of lakes (Rao and Schwab, 2007; Chen et al., 2011; Juma et al., 2014). Studies have found that the pollutant input from inflow rivers has a 
meaningful effect on the nutrient concentration with certain relationships (Zhang et al., 2016).

As one of the five largest fresh lake and a long-term eutrophic water body in China, many efforts have been undertaken by researchers and government entities to restore the Lake Taihu since 1990, including sediment dredging, wetland construction, water transfer projects, the use of macrophytes and so on (Hu et al., 2010; Li et al., 2011a, 2013). Researchers have shown that increasing the amount of pollutant discharge into the lakes is crucial, and efforts to control the nutrient input from the catchment of Lake Taihu are essential (Chen et al., 2003; Qin et al., 2007; Wang et al., 2011). In addition to light, temperature and salinity, nitrogen $(\mathrm{N})$ and phosphorus $(\mathrm{P})$ are the most common factors of limiting algal growth and relevant control has been widely implemented to address eutrophication in many freshwater system (Nixon, 1995; Schindler and Vallentyne, 2008; Conley et al., 2009; Suttle and Harrison, 2010; Xu et al., 2010, 2015). With the tendency of being co-limited by $\mathrm{N}$ and $\mathrm{P}$ in Lake Taihu, evidence suggests that the lake has been in a nutrient-imbalance condition owing to focusing more on $\mathrm{P}$ reduction rather than together these two elements (Paerl, 2009; Lewis et al., 2011; Tang et al., 2016). In general, the pollution level of nitrogen and phosphorus is indicated by total nitrogen (TN) and total phosphorous (TP), and some studies have estimated the TN reduction in Lake Taihu and its inflow rivers (Du et al., 2017). Meanwhile, ammonia nitrogen $\left(\mathrm{NH}_{4}{ }^{+}-\mathrm{N}\right)$ is one of the three main forms of $\mathrm{TN}$ in natural water, and studies have indicated that $\mathrm{NH}_{4}{ }^{+}-\mathrm{N}$ has tightly coupled relationships with $\mathrm{TN}$ and water quality in Lake Taihu Basin (Liang et al., 2008; Ferard and Blaise, 2013). Therefore, this study focuses on the spatiotemporal dynamics of $\mathrm{NH}_{4}{ }^{+}-\mathrm{N}$ and its response to inflow river. In the interactional study of eutrophication, hydrodynamics and ecosystem in various freshwater bodies, lots of mathematical modelling approaches have been extensively applied to simulate the flow, water quality, spatiotemporal pattern of hydrodynamics and so on (Rasmussen et al., 2009; Min and Wise, 2010; Zhang et al., 2017). For instance, Mike21, a two-dimensional mathematic model, has been usually used to calculated aquatic environment capacity and total emission reduction according to aquatic environmental functions and targets (DHI, 2007; Zhu et al., 2013; Zhang, 2017). Several empirical models, such as the Wisconsin Department of Natural Resources' (WDNR) Wisconsin Lakes Modelling Suite, Seepage Lake Model and BATHTUB, have been previously developed and tested for predicting eutrophication-related water quality conditions in complex lakes and reservoirs (USEPA, 2000, 2010; WDNR, 2004; MPCA, 2006). However, these methods usually have certain data requirements or index restrictions (Wang et al., 2005). Random forest (RF) is a new machine learning algorithm and is combined with a predictor of multiple decision trees. It was proposed as a new soft computing method (Breiman et al., 1984). The RF has been developed to optimise predictive performance because of its several advantages, including a limited number of user defined parameters and the capability to model nonlinear relationships; reduce overfitting; remain robust despite of missing data and outliers; manage qualitative and quantitative variables; and evaluate, summarise and interpret final models (Breiman, 2001; Friedman, 2001; Friedman and Meulman, 2010). Over the past years, RF has been successfully applied to simulate soil organic carbon stocks, suspended sediment concentration, $\mathrm{NO}_{2}$ concentration and nutrient concentrations (such as chemical oxygen demand); during these simulations, RFs have high tendency (Francke et al., 2008; Were et al., 2015; Rodriguez-Galiano et al., 2015; Ye et al., 2018; Muthukrishnan et al., 2018; Marttila et al., 2018; Kaminska, 2019). 
The present work took the northwest Lake Taihu as an example for the analysis. Generally, this study aims to (1) analyse the temporal and spatial variations in $\mathrm{NH}_{4}{ }^{+}-\mathrm{N}$ in the lake and its inflow rivers; (2) develop RF model to simulate the correspondence between the $\mathrm{NH}_{4}{ }^{+}-\mathrm{N}$ concentrations in the lake and its inflow rivers; and (3) address the water quality in the northwest Lake Taihu response to the river inflow.

\section{Materials and Methods}

\section{Study area}

As the third largest freshwater lake in China, Lake Taihu is situated in Southeast Jiangsu Province and the lower reach of the Yangtze River Basin with a surface area of $2338 \mathrm{~km}^{2}$ and drainage area of $36500 \mathrm{~km}^{2}$ (Lake Taihu Basin Authority, 2012). Lake Taihu is the main drinking water source for its neighbouring residents despite being heavily polluted and inferior to Grade V in GB3838-2002 (Bai et al., 2009). With the deterioration of environment and water quality, it has caused serious pollution in the lake ecosystems and algal blooms have long been frequency and concerning phenomenon, especially northwest part of the lake, and rivers flowing into Lake Taihu are the crucial factor (Qin et al., 2008; Tao et al., 2018). Excessive nutrients from inflow rivers are the major source of pollutant loadings to the lake and subsequently lead to spatial heterogeneity ( $\mathrm{Li}$ et al., 2013; Liu et al., 2017). Lake Taihu has a tanglesome river and channel network, and more than 200 rivers at different scales are connected to it (Zhang et al., 2014). As shown in Fig. 1, the inflow rivers are primarily located in the northwest regions, covering North Zone, Zhushan Bay, Meiliang Bay and Gonghu Bay, and the outflows in the eastern and southern part of the lake (Du et al., 2017; Li et al., 2019). Inflow rivers in northwest Lake Taihu contribute the most water discharge and nearly $80 \%$ of COD, N and P to the lake (Zhang and Chen, 2011). Eutrophication studies in Lake Taihu have often focused on $\mathrm{P}$ because it is the most universal limiting nutrient and is thus typically targeted for loading reduction (Morton et al., 2003; Niu et al., 2004; Schindler, 2006; Lewis and Wurtsbaugh, 2008). Nevertheless, it is fundamentally important and cannot be ignored to control $\mathrm{N}$ inputs. Therefore, the present work focuses on the $\mathrm{NH}_{4}{ }^{+}-\mathrm{N}$ concentrations in northwest Lake Taihu and its inflow rivers based on the monthly monitoring data covering the period of 2009-2015.

\section{Data analysis}

Monthly $\mathrm{NH}_{4}{ }^{+}-\mathrm{N}$ concentrations of inflow rivers and of northwest Lake Taihu during the period of 2009-2015 were provided by Jiangsu Province Hydrology and Water Resources Investigation Bureau. The locations of the monitoring sites distributed across northwest Lake Taihu and its inflow rivers are shown in Fig. 1. These monitoring stations were located by GPS, and water samples were collected monthly from 2009 to 2015, from approximately $1 \mathrm{~m}$ below the water. The samples were then delivered to a laboratory by cryopreservation, and their correlation processing, such as the sampling, preservation, transportation and analysis, were performed within $24 \mathrm{~h}$. All the samples were measured three times, and results were expressed in average. All chemical analyses followed the standards established by the State Environmental Protection Bureau of China.

For the convenience of describing the influences of the inflow rivers, Lake Taihu was divided into seven sub-areas (Fig. 1), namely, North Zone, Zhushan Bay, Meiliang Bay, 
Gonghu Bay, Southwest Zone, Central Zone, East Epigeal Zone and Dongtaihu Bay (Hu et al., 2008; Li et al., 2011b). This study focuses on the $\mathrm{NH}_{4}{ }^{+}-\mathrm{N}$ concentration in northwest Lake Taihu and thus included only the sub-lakes of North Zone, Zhushan Bay, Meiliang Bay, Gonghu Bay and their inflow rivers. In view of data availability and the links between the sub-lakes and their inflow rivers, corresponding sites were selected, as shown in Fig. 2.

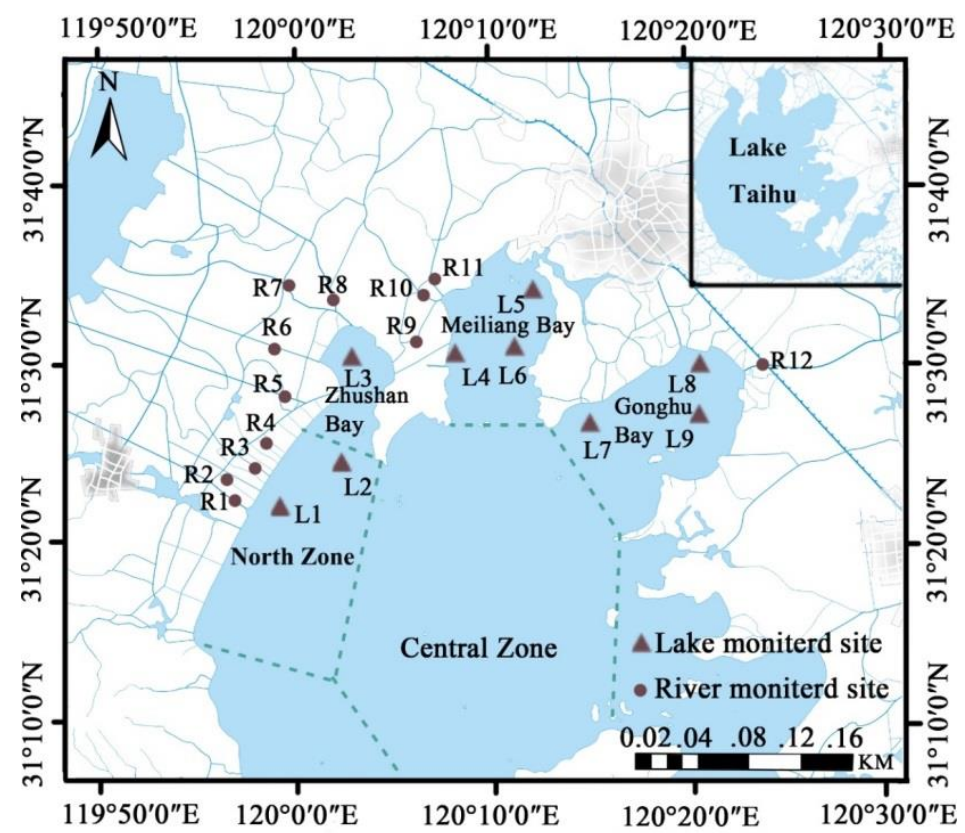

Figure 1. Study area and its monitoring sites

\section{Model description}

A RF model is made up of a number of simple (binary) decision trees, which were predetermined by a subset of predictors with the random selection strategy and grown on a bootstrap sample of the training set (Breiman, 2001). An RF makes no any additional assumptions about either the dependent or independent variables and could describe nonlinear and linear relationships (Cutler et al., 2007). The final model predictions are the average of the forest predictions and this method has been successfully used in analysis of many fileds (Maraqa et al., 2007; Paliwal and Patra, 2011). Despite the optimise predictive performance and wide potential, the complex relationship between pollutant concentrations and ambient conditions couldn't be provided and satisfactory descripted in this model (Khan et al., 2017; Kaminska, 2019).

Three important parameters, the number of trees to grow in the forests (ntree), the number of randomly selected predictor variables at each node (mtry) and the minimal number of observations at the terminal nodes of the trees (nodesize), must be specified in the RF model. Ntree is the most important one since its determination of the strength of each individual tree and correlation among trees (Peters et al., 2008). The random in an $\mathrm{RF}$ is performed by randomizing the observed subsets and mtry candidate variables both, which influence the tree and the split creation in the tree respectively. Mulitdimensional step function is produced by each individual tree, which results in that the average of the individual tree is a multidimensional step function, namely the whole 
prediction of the forest. The multidimensional step function can predict smooth function as it has large number of sample values (Gromping and Ulrike, 2009).

In order to determine the fitting quality of each model, several possible error functions were computed and considered in the present work. As one of the basic measures to estimate a model's goodness of fit, the coefficient of determination $R^{2}$ is fundamental and the value ranges between $\langle 0,1\rangle$. The closer it is to 1 , the smaller are the differences between the empirical values and the estimated values.

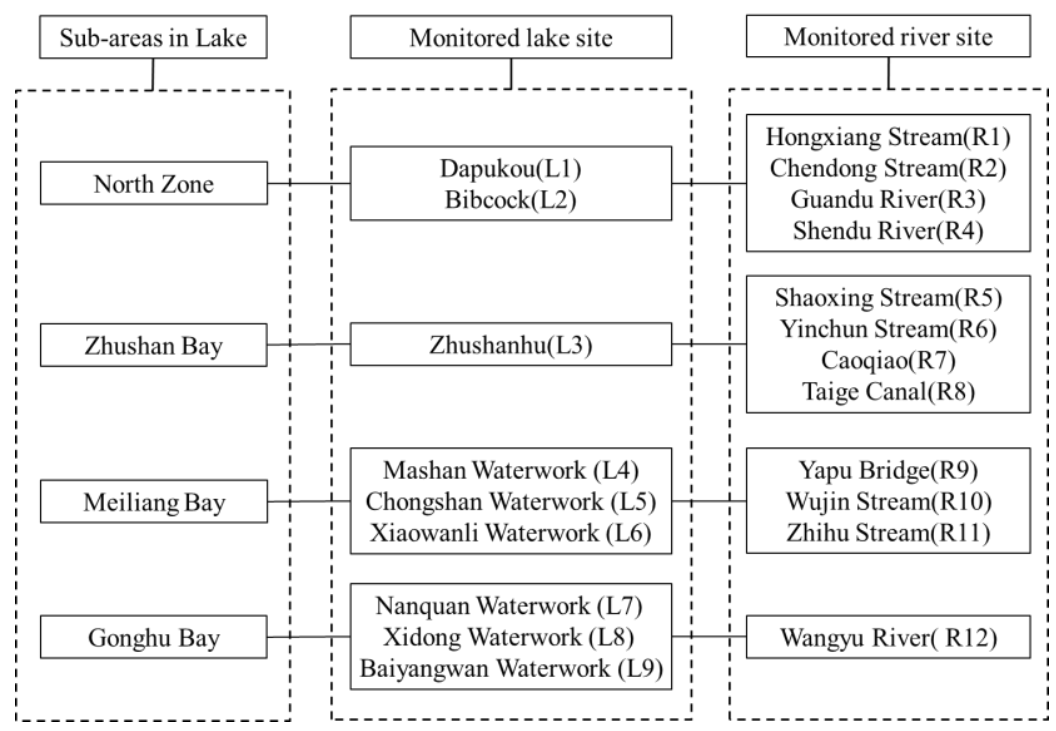

Figure 2. Sampling stations in Lake Taihu and its inflow rivers

\section{Model scenarios}

Developing effective and feasible nutrient reduction targets is necessary to improve trophic status and reduce bloom potentials. According to the Environmental Quality Standards for Surface Water in China (GB3838-2002) (Table 1), two nutrient reduction modeling scenarios were con-ducted to assess water quality response to nutrient load reductions in this study (Table 2).

Table 1. The standard of $\mathrm{NH}_{4}{ }^{+}-\mathrm{N}$ in the Environmental Quality Standards for Surface Water in China (GB3838-2002) ( $\mathrm{mg} / \mathrm{L})$

\begin{tabular}{c|c|c|c|c|c}
\hline & Class I & Class II & Class III & Class IV & Class V \\
\hline $\mathbf{N H}_{4}{ }^{-}-\mathbf{N}(\underline{\leq})$ & 0.15 & 0.5 & 1.0 & 1.5 & 2.0 \\
\hline
\end{tabular}

Table 2. Nutrient reduction scenarios and Water quality targets

\begin{tabular}{c|c|c|c|c}
\hline & North Zone & Zhushan Bay & Meiliang Bay & Gonghu Bay \\
\hline Scenario 1 & Class III & Class III & Class II & Class II \\
\hline Scenario 2 & Class II & Class II & Class I & Class I \\
\hline
\end{tabular}

There is a possibility that water circumstances could be altered by climate change in the future which is not easy to control. Although the answers are clearer now that nutrients, light, temperature and hydrodynamic force have all have been shown to 
influence formation of cyanobacterial blooms, the mechanism of a specific cyanobacterial bloom remains unknown (Qin et al., 2013). For example, temperature, precipitation and the distribution the runoff water have significant effect on the ammonium concentration and they are so complex and hard to predictable (Qin et al., 2010; Paerl et al., 2014). However, anthropogenic nutrient reduction to control water quality in lake is a direct and potentially achievable step that can be taken (Paerl et al., 2011; Xu et al., 2015). The two scenarios were made according to the water quality targets for the northwest Taihu Lake in the Master Plan of Integrated Regulation of Water Environment and the Water Function Zoning of the Lake Taihu Basin.

\section{Results and Discussion}

\section{Spatiotemporal distribution of $\mathrm{NH}_{4}^{+}-\mathrm{N}$ in northwest Lake Taihu}

The northwest Lake Taihu area is the most contaminated and has yet to be studied in detail. Thus, it was selected for the analysis of the spatial and temporal changes that occurred in 2009-2015. The spatiotemporal distribution of $\mathrm{NH}_{4}{ }^{+}-\mathrm{N}$ in North Zone, Zhushan Bay, Meiliang Bay and Gonghu Bay are detailed as follows.

In the northwest Lake Taihu, the spatiotemporal distribution patterns of nutrient concentrations are distinct. In general, ammonia concentration tends to decrease gradually from 2009 to 2015 (Fig. 3).

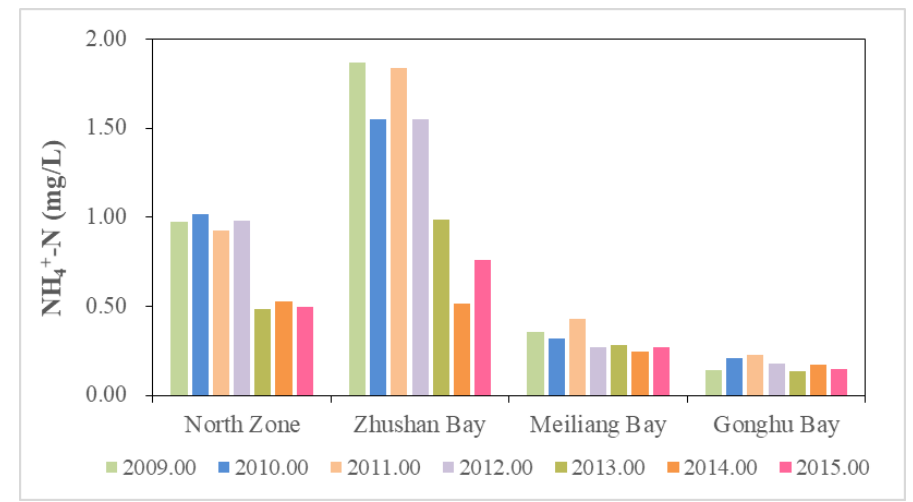

Figure 3. Yearly mean values of $\mathrm{NH}_{4}{ }^{+}-\mathrm{N}$ concentration in northwest Lake Taihu

The North Zone and Zhushan Bay were the two heavily polluted areas, whereas Gonghu Bay was in the best and cleanest condition. The range of $\mathrm{NH}_{4}{ }^{+}-\mathrm{N}$ concentration in the North Zone and Zhushan Bay was $0.5-2.5 \mathrm{mg} / \mathrm{L}$, whereas those in Meiliang Bay and Gonghu Bay were approximately $0.5 \mathrm{mg} / \mathrm{L}$ (Fig. 4). The Environmental Quality Standards for Surface Water in China (GB3838-2002) has indicated that the $\mathrm{NH}_{4}{ }^{+}-\mathrm{N}$ concentration in the North Zone and Zhushan Bay is classified as Class III-V, and that in the other two lake regions is classified as Class I or II; this classification indicates that the further consideration of the limiting nutrient in the North Zone and Zhushan Bay is important prior to other lake regions. The $\mathrm{NH}_{4}{ }^{+}-\mathrm{N}$ content in the four seasons (that is, Winter: December, January and February; Spring: March, April and May; Summer: June, July and August; and Autumn: September, October and November) in northwest Lake Taihu were calculated (Table 3). The standard deviations of monthly mean values of $\mathrm{NH}_{4}{ }^{+}-\mathrm{N}$ concentration in northwest Lake Taihu in Fig. 4 are 0.52, 0.8, 
0.1 and 0.09 , separately. The results showed that season had a considerable effect on the $\mathrm{NH}_{4}{ }^{+}-\mathrm{N}$ concentration of northwest Lake Taihu, which was remarkably higher in winter and spring than those in other seasons. In the studied area, the $\mathrm{NH}_{4}{ }^{+}-\mathrm{N}$ concentration was the highest in winter. Therewith, the concentration started gradually decreasing in spring. Finally, it dropped to the minimum value in the summer or autumn. The seasonal tendency in the four regions was similar and especially evident in the North Zone and Zhushan Bay. The variations of concentrations in different seasons were in accordance with the change trend of air temperature. The solubility of ammonia nitrogen in water decreases with temperature increasing. What's more, these winter maxima possibly arise from (1) around lake, surface and subsurface catchment inputs are high in the non-growing season; (2) nutrients are concentrated in lower water levels; and (3) microbial activity is low due to low temperatures (Wang et al., 2017). It also may due to the relationships between ammonium loadings and rainfall, that's precipitation had a summer maximum and a fall minimum and followed an inverse seasonal cycle compared to $\mathrm{NH}_{4}{ }^{+}-\mathrm{N}$ concentrations (Nõges et al., 2007).

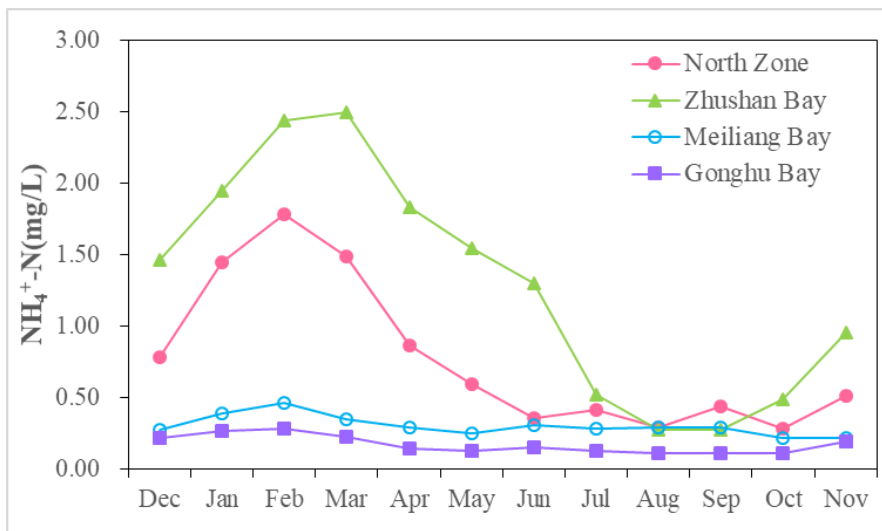

Figure 4. Monthly mean values of $\mathrm{NH}_{4}{ }^{+}-\mathrm{N}$ concentration in northwest Lake Taihu

Table 3. Monthly mean values of $\mathrm{NH}_{4}{ }^{+}-\mathrm{N}$ concentration in northwest Lake Taihu $(\mathrm{mg} / \mathrm{L})$

\begin{tabular}{c|c|c|c|c}
\hline & North Zone & Zhushan Bay & Meiliang Bay & Gonghu Bay \\
\hline Winter & 1.34 & 1.96 & 0.38 & 0.26 \\
Spring & 0.98 & 1.95 & 0.30 & 0.17 \\
Summer & 0.35 & 0.70 & 0.29 & 0.13 \\
Autumn & 0.41 & 0.57 & 0.24 & 0.14 \\
\hline
\end{tabular}

\section{$\mathrm{NH}_{4}^{+}-\mathrm{N}$ input from inflow rivers in northwest Lake Taihu}

The annual $\mathrm{NH}_{4}{ }^{+}-\mathrm{N}$ loads to the northwest Lake Taihu from its tributaries mean a large amount of nutrients and pollutant. Besides Gonghu Bay, $\mathrm{NH}_{4}{ }^{+}-\mathrm{N}$ concentrations of inflow rivers in the regions were classified as Class IV-V or worse. By contrast, the water quality of inflow rivers in Gonghu Bay was relatively good. The $\mathrm{NH}_{4}{ }^{+}-\mathrm{N}$ concentrations in the main inflow rivers in northwest Lake Taihu directly affected the northwest lake regions from 2009 to 2015 , as shown in Fig. 5. The $\mathrm{R}^{2}$ values of these scatter diagrams are all approximately 0.70 (that is, $0.763,0.775,0.641$ and 0.758 ), and $\mathrm{p}<0.01$ (Fig. 5). In conclusion, river inputs are the major source of $\mathrm{NH}_{4}{ }^{+}-\mathrm{N}$ loadings to the northwest Lake Taihu, and water quality in the lake is closely related to that in 
inflow rivers. Declining water quality in inflow rivers have a considerable influence on lake restoration, and $\mathrm{NH}_{4}{ }^{+}-\mathrm{N}$ concentrations evidently decrease with the reduction of inflow load.
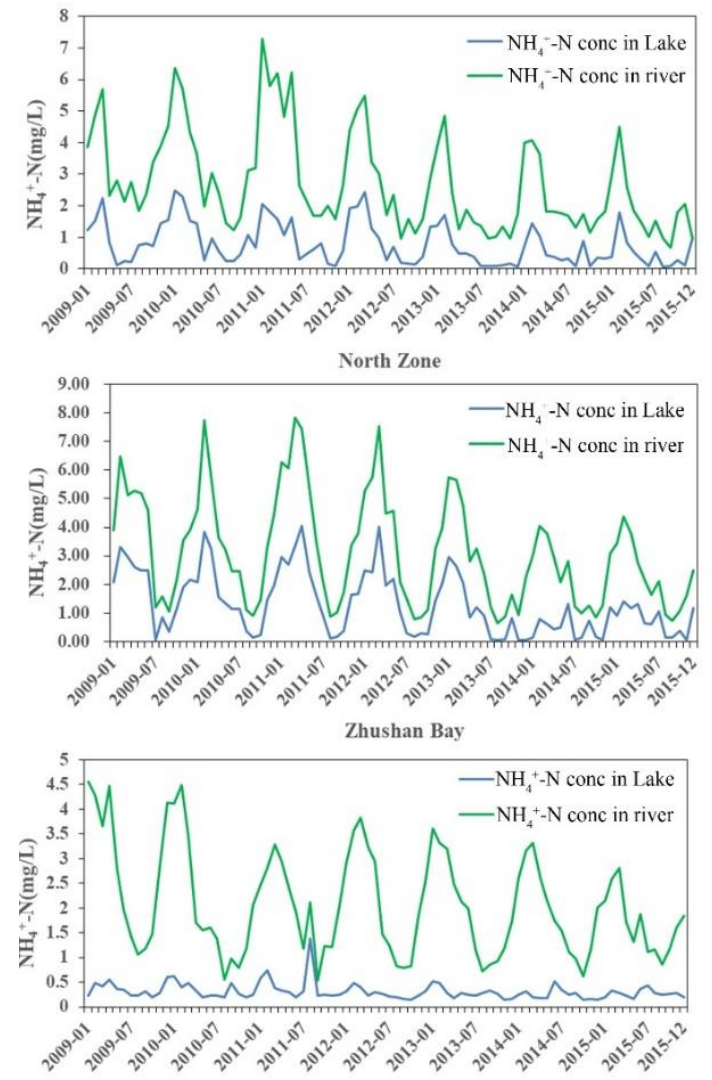

Meiliang Bay

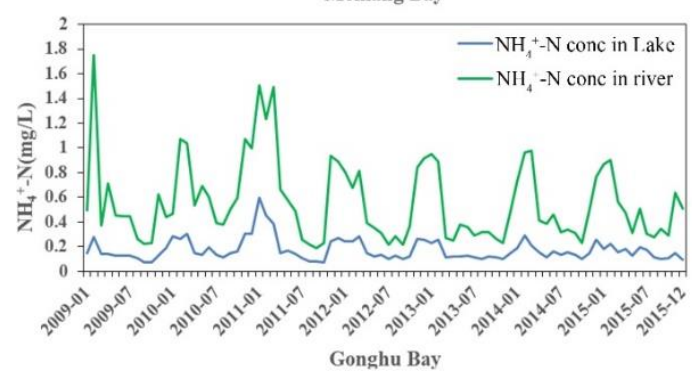

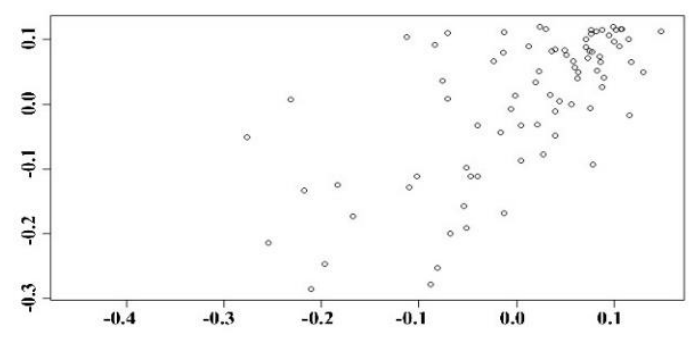

The scatter diagrams of $\mathrm{NH}_{4}^{+}-\mathrm{N}$ in North Zone and inflow rivers

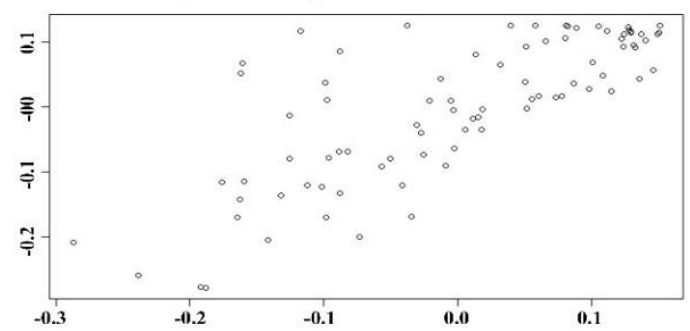

The seatter diagrams of $\mathrm{NH}_{4}^{+}-\mathrm{N}$ in $\mathrm{Zhushan}$ Bay and inflow rivers

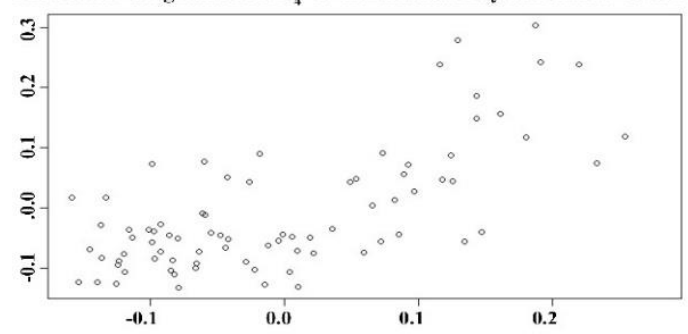

The scatter diagrams of $\mathrm{NH}_{4}^{+}-\mathrm{N}$ in $\mathrm{Zhushan}$ Bay and inflow rivers

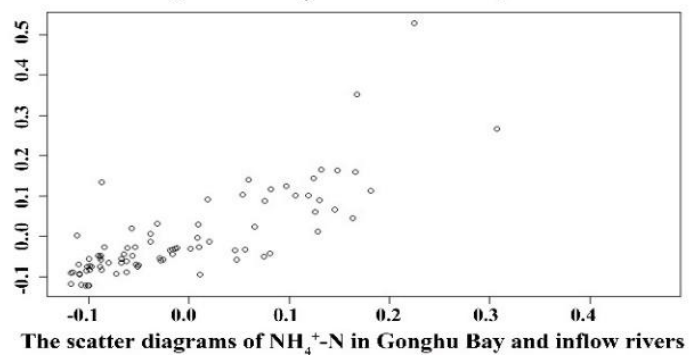

Figure 5. Monthly mean values of $\mathrm{NH}_{4}{ }^{+}-\mathrm{N}$ concentration in northwest Lake Taihu and its inflow rivers from 2009 to 2015 and the scatter diagrams in corresponding regions

\section{System response to nutrient reduction}

\section{Simulated results in $R F$ model}

By using the acquired monitoring data, the RF model set up the forecast model between the water quality of monitoring sites in the lake $\left(\mathrm{NH}_{4}{ }^{+}-\mathrm{N}\right.$ concentrations) and its inflow rivers $\left(\mathrm{NH}_{4}{ }^{+}-\mathrm{N}\right.$ loads). Given the relatively small dataset, every one of the seventh data were extracted as the testing stage, whereas the others are randomly assigned as the training stage after sorting the monthly monitoring data during 2009-2014, thereby ensuring that the RF model was fully calibrated. Then the data of 
2015 in the inflow rivers were the independent validation set and used to test the model. The simulation results showed that the values of $\mathrm{R}^{2}$ in the training stage of $\mathrm{NH}_{4}{ }^{+}-\mathrm{N}$ were $0.87,0.95,0.73$ and 0.97 in the RF model for the four pairs of lake and river stations. Meanwhile, the values of $\mathrm{R}^{2}$ in the testing stage of $\mathrm{NH}_{4}{ }^{+}-\mathrm{N}$ were $0.53,0.52$, 0.57 and 0.58 in the RF model. Moreover, the data of 2015 in the inflow rivers were used to the established model to stimulate the water quality in the lake. As shown in Fig. 6, the relationships between the measured $\mathrm{NH}_{4}{ }^{+}-\mathrm{N}$ concentration and those predicted by the RF are proved to have good curve fitting characteristics. Consequently, the established RF model had a relatively high precision, and the forecast model could be used in the next step of stimulating the scene of water quality in the northwest Taihu Lake.
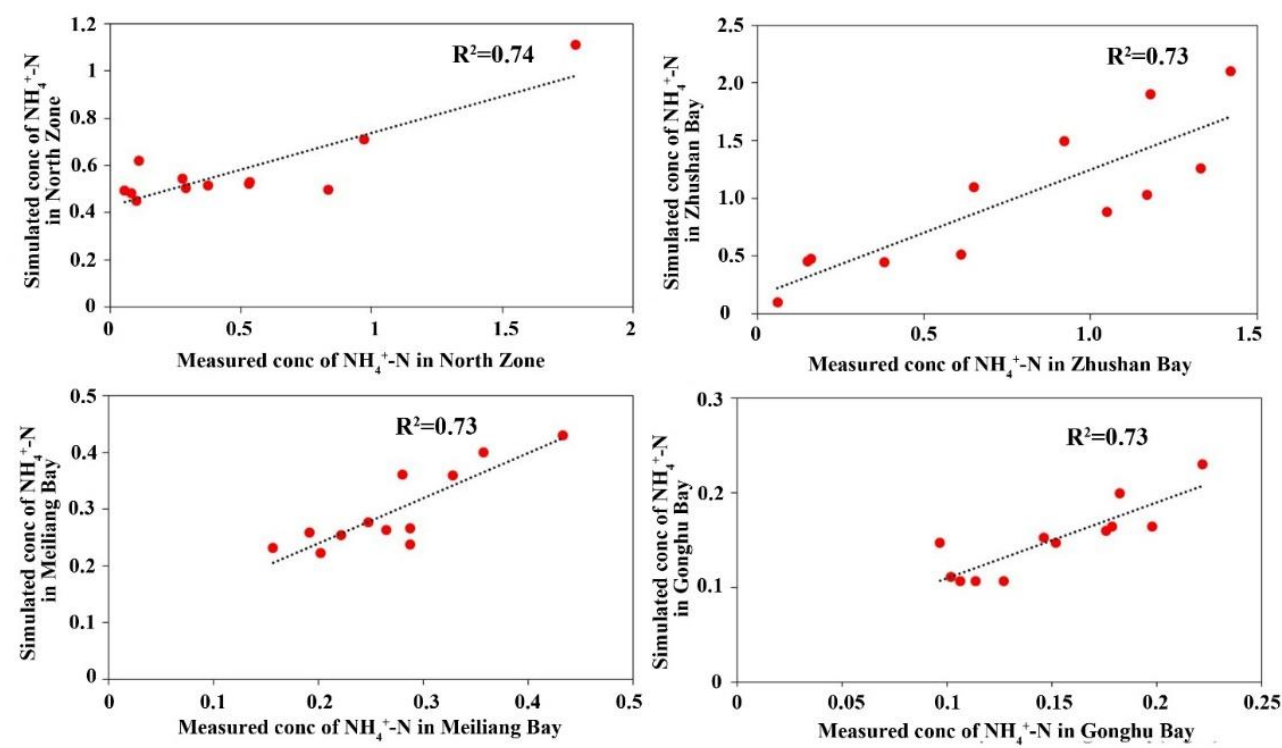

Figure 6. Measured and simulated $\mathrm{NH}_{4}{ }^{+}-\mathrm{N}$ concentration in 2015 in the $\mathrm{RF}$ model $(\mathrm{mg} / \mathrm{L})$

The Master Plan of Integrated Regulation of Water Environment of Taihu Basin, which was ratified by the State Council in 2008 and revised in 2013, had proposed the control targets of water quality indices in the lake (TN-Class $\mathrm{V}$ ) for agricultural irrigation purpose. In addition, the Chinese State Council ratified the Master Plan of Integrated Regulation of Water Environment and the Water Function Zoning of the Lake Taihu Basin, thereby initiating the comprehensive treatment of the water environment in the basin. On the basis of the master plan, the $\mathrm{NH}_{4}{ }^{+}-\mathrm{N}$ protective goals of the North Zone and Zhushan Bay belong to Class III, and those of Meiliang Bay and Gonghu Bay belong to Class II. As mentioned in Section 3.1, research has shown that $\mathrm{NH}_{4}{ }^{+}-\mathrm{N}$ concentrations in the North Zone and Zhushan Bay were classified as Class III-V, whereas those in other two lake regions were classified as Class I or II. The setting of the $\mathrm{NH}_{4}{ }^{+}-\mathrm{N}$ concentration in the lake as the target value should continuously debug the $\mathrm{NH}_{4}{ }^{+}-\mathrm{N}$ concentration in the inflow rivers and allow the target value to be predicted in the debugged RF models (Table 4). Consequently, for the protective targets in the Master Plan of Integrated Regulation of Water Environment and the Water Function Zoning of the Lake Taihu Basin [Scenario 1: North Zone and Zhushan Bay (Class III), Meiliang Bay and Gonghu Bay (Class II )], the inflow loads should be 
controlled under $6427.38,3248.01,2206.92$ and $1107.58 \mathrm{t}^{-1}$, respectively. The total $\mathrm{NH}_{4}{ }^{+}-\mathrm{N}$ loads in the northwest Lake Taihu should be maintained under $12989.89 \mathrm{t}^{-1}$. To achieve better water quality goal in Scenario 2 [North Zone and Zhushan Bay (Class II ), and Meiliang and Gonghu Bays (Class I)], the inflow loads in the North Zone , Zhushan Bay, Meiliang Bay and Gonghu Bay should be maintained under 3304.64, 2466.53, 615.26 and $281.93 \mathrm{t}^{-1}$, respectively. The total $\mathrm{NH}_{4}{ }^{+}-\mathrm{N}$ loads from the northwest Lake Taihu should be maintained under $6668.37 \mathrm{t}^{-1}$.

Table 4. Water quality goals in the lake and statistics of water quality values in different scenarios

\begin{tabular}{c|c|c|c|c|c}
\hline \multirow{2}{*}{ Sub-lake } & Water functional zone & \multicolumn{2}{|c|}{ Scenario 1 } & \multicolumn{2}{c}{ Scenario 2 } \\
\cline { 3 - 5 } & $\begin{array}{c}\text { Goal in lake } \\
(\mathbf{m g} / \mathbf{L})\end{array}$ & $\begin{array}{c}\text { Inflow loads } \\
\left(\mathbf{t a}^{-\mathbf{1}}\right)\end{array}$ & $\begin{array}{c}\text { Goal in lake } \\
(\mathbf{m g} / \mathbf{L})\end{array}$ & $\begin{array}{c}\text { Inflow loads } \\
\left.\mathbf{( t a}^{-\mathbf{1}}\right)\end{array}$ \\
\hline North Zone & $\begin{array}{c}\text { Conservation areas of Lake } \\
\text { Taihu }\end{array}$ & 1.0 (III) & 6427.38 & 0.5 (II) & 3304.64 \\
Zhushan Bay & $\begin{array}{c}\text { Conservation areas of Zhushan } \\
\text { Lake }\end{array}$ & 1.0 (III) & 3248.01 & 0.5 (II) & 2466.53 \\
Meiliang Bay & $\begin{array}{c}\text { Conservation areas of water } \\
\text { scenery }\end{array}$ & 0.5 (II) & 2206.92 & 0.15 (I) & 615.26 \\
Gonghu Bay & $\begin{array}{c}\text { Conservation areas of drinking } \\
\text { water source }\end{array}$ & 0.5 (II) & 1107.58 & 0.15 (I) & 281.93 \\
\hline
\end{tabular}

\section{Influences of loads on $\mathrm{NH}_{4}^{+}-\mathrm{N}$}

The overall results indicated that the $\mathrm{NH}_{4}{ }^{+}-\mathrm{N}$ concentrations evidently decreased with the inflow loads in the lake regions. In 2015, the $\mathrm{NH}_{4}{ }^{+}-\mathrm{N}$ loads from inflow rivers were less than the standards in Scenario 1, and the $\mathrm{NH}_{4}{ }^{+}-\mathrm{N}$ concentrations in the four lake regions agreed with the simulation results in RF models in Table 5, that's the $\mathrm{NH}_{4}{ }^{+}-\mathrm{N}$ concentration in the North Zone and Zhushan Bay were classified as Class III and Meiliang Bay and Gonghu Bay were classified as Class II , which once again proved the practicability of the simulated results of the RF models. The $\mathrm{NH}_{4}{ }^{+}-\mathrm{N}$ concentrations in the four lake regions achieved the basic goals in the Master Plan of Integrated Regulation of Water Environment and the Water Function Zoning of the Lake Taihu Basin. Under $8.99 \%$ reduction of inflow loads in the North Zone, the water quality in this region could be suitable to Class II. Similarly, the $\mathrm{NH}_{4}{ }^{+}-\mathrm{N}$ loads from the inflow rivers of the North Zone, Zhushan Bay, Meiliang Bay and Gonghu Bay should be reduced by nearly $8.99 \%, 11.41 \%, 51.38 \%$ and $62.87 \%$, respectively, for better water quality in the lake regions (the $\mathrm{NH}_{4}{ }^{+}-\mathrm{N}$ concentrations decreased by approximately $6 \%, 34 \%, 44.44 \%$ and $6.67 \%$, respectively). The total $\mathrm{NH}_{4}{ }^{+}-\mathrm{N}$ loads from the inflow rivers of northwest Lake Taihu should be maintained under $6668.37 \mathrm{t}^{-1}$, which is $20.96 \%$ lower than that in 2015 .

Table 5. Mass budgets for $\mathrm{NH}_{4}{ }^{+}-\mathrm{N}$ in inflow rivers in northwest Lake Taihu and load reductions in two scenarios in contrast to the situation in 2015

\begin{tabular}{c|c|c|c|c}
\hline & $\begin{array}{c}\mathbf{N H}_{4}^{+}-\mathbf{N} \text { loads from } \\
\text { inflow rivers }\end{array}$ & $\begin{array}{c}\mathbf{N H}_{4}^{+}-\mathbf{N} \text { concentrations in } \\
\text { the lake regions }\end{array}$ & $\begin{array}{c}\text { In comparison to } \\
\text { Scenario 1 }\end{array}$ & $\begin{array}{c}\text { In comparison to } \\
\text { Scenario 2 }\end{array}$ \\
\hline North Zone & 3627.83 & $0.53(\mathrm{III})$ & $-77.17 \%$ & $+8.91 \%$ \\
Zhushan Bay & 2784.15 & $0.76(\mathrm{III})$ & $-16.66 \%$ & $+11.41 \%$ \\
Meiliang Bay & 1265.52 & $0.27(\mathrm{II})$ & $-74.39 \%$ & $+51.38 \%$ \\
Gonghu Bay & 759.31 & $0.16(\mathrm{II})$ & $-45.87 \%$ & $+62.87 \%$ \\
\hline
\end{tabular}




\section{Conclusions}

In the present study, monthly $\mathrm{NH}_{4}{ }^{+}-\mathrm{N}$ water quality data in inflow rivers and corresponding sub-lake were used to analyse the $\mathrm{NH}_{4}{ }^{+}-\mathrm{N}$ distributions in northwest Lake Taihu. RF models were constructed to simulate the correspondence between the $\mathrm{NH}_{4}{ }^{+}-\mathrm{N}$ concentrations in the lake and its inflow rivers in different scenarios.

In the northwest Lake Taihu, the spatiotemporal distribution patterns of nutrient concentrations are distinct, and river inputs were the major source of $\mathrm{NH}_{4}{ }^{+}-\mathrm{N}$ loadings to the northwest Lake Taihu. The North Zone and Zhushan Bay were the most seriously polluted among the lake areas, whereas Gonghu Bay was the cleanest region. In winter and spring, $\mathrm{NH}_{4}{ }^{+}-\mathrm{N}$ concentrations were significantly higher than in summer and autumn, and seasons had a significant effect on the $\mathrm{NH}_{4}{ }^{+}-\mathrm{N}$ concentrations of northwest Lake Taihu. In the RF models, the $\mathrm{R}^{2}$ and relationships between measured $\mathrm{NH}_{4}{ }^{+}-\mathrm{N}$ concentrations and those predicted by the RF proved that the established RF models had a relatively high precision and that the forecast model could be used in the further stimulation of the scene of water quality in northwest Taihu Lake. In 2015, the $\mathrm{NH}_{4}{ }^{+}-\mathrm{N}$ loads from inflow rivers were less than the standards in Scenario 1, and the $\mathrm{NH}_{4}{ }^{+}-\mathrm{N}$ concentrations in the four lake regions agreed with the simulation results in RF models. For the protective targets [Scenario 1: North Zone and Zhushan Bay (Class III), Meiliang Bay and Gonghu Bay (Class II )], the inflow loads should be controlled under 6427.38, 3248.01, 2206.92 and $1107.58 \mathrm{t}^{-1}$, respectively. To achieve better water quality goal for North Zone and Zhushan Bay (Class II ), Meiliang Bay and Gonghu Bay (Class I), the inflow loads should be maintained under 3304.64, 2466.53, 615.26 and $281.93 \mathrm{t}^{-1}$, respectively. The nutrient reduction scenarios showed that $\mathrm{NH}_{4}{ }^{+}-\mathrm{N}$ concentrations decreased by approximately $6 \%, 34 \%, 44.44 \%$ and $6.67 \%$ in the North Zone, Zhushan Bay, Meiliang Bay and Gonghu Bay, despite the reduction of external $\mathrm{NH}_{4}{ }^{+}-\mathrm{N}$ loads by $8.99 \%, 11.41 \%, 51.38 \%$ and $62.87 \%$, respectively.

Eutrophication and algal blooms are worldwide environmental issues in lakes and the eutrophication process and forming mechanisms of algal blooms are particularly complicated in shallow lakes due to the strong lake-land, air-water and water-sediment interactions (Qin et al., 2007). This study provides further understand on the water quality distribution pattern in Lake Taihu, quantifying the reduction of nutrient loading from inflow rivers and governing Lake Taihu or other typical eutrophic lakes. However, only the northwest Lake Taihu Basin was studied instead of the entire lake, and only monthly $\mathrm{NH}_{4}{ }^{+}-\mathrm{N}$ monitoring data during 2009-2015 were utilised as modelling variables instead of using other indices. Additional water quality indices and theoretical explorations are still needed in future works. Thus, stricter external nutrient managements and other ecological restoration tools must still be considered and investigated for the water environment recovery and protection in the Taihu basin. Under the control of exogenous nutrients, the variation characteristics and distribution of nutrient concentration in eutrophicated shallow lakes are closely related to the hydrodynamic process of shallow lakes and the action of underlying lake flow (Jing et al., 2000). At the same time, submerged plants can contain the dynamic suspension process of sediments, absorb nutrients in water and sediments, reduce the load of nutrients, and purify the water quality of lakes (Jöbgen et al., 2004; Wang et al., 2019). Therefore, it also shows that it is not enough to govern Taihu lake only by controlling external pollution, and the treatment of internal pollution of Taihu lake also needs to be strengthened. 
Acknowledgements. This study was supported by the Strategic Priority Research Program of the Chinese Academy of Sciences (Grant No. XDA23020201), the Water Conservancy Science and Technology Project of Jiangsu Province (Grant No. 2018042 and No. 2014031). The authors would like to thank Jiangsu Province Hydrology and Water Resources Investigation Bureau for their assistance during the research.

\section{REFERENCES}

[1] Bai, X., Ding, S., Fan, C., Liu, T., Shi, D., Zhang, L. (2009): Organic phosphorus species in surface sediments of a large, shallow, eutrophic lake, Lake Taihu, China. Environmental Pollution 157: 2507-13.

[2] Bian, B., Zhou, Y., Fang, B. B. (2016): Distribution of heavy metals and benthic macroinvertebrates: impacts from typical inflow river sediments in the Taihu basin, China. - Ecological Indicators 69: 348-359.

[3] Breiman, L., Friedman, J., Stone, C. J., Olshen, R. A. (1984): Classification and Regression Trees, the Wadsworth and Brooks-cole Statistics-probability Series. - Taylor \& Francis.

[4] Breiman, L. (2001): Random forests. - Machine Learning 45: 5-32.

[5] Chen, Y., Qin, B., Teubner, K., Dokulil, M. T. (2003): Long-term dynamics of phytoplankton assemblages: microcystis-domination in lake Taihu, a large shallow lake in China. - Journal of Plankton Research 25(4): 445-453.

[6] Chen, S., Huang, W., Chen, W., Wang, H. (2011): Remote sensing analysis of rainstorm effects on sediment concentrations in Apalachicola Bay, USA. - Ecological Informatics 6(2): 147-155.

[7] Conley, D. J., Paerl, H. W., Howarth, R. W., Boesch, D. F., Seitzinger, S. P., Havens, K. E., Lancelot, C., Likens, G. E. (2009): Controlling eutrophication: nitrogen and phosphorus. - Science 323(5917): 1014-1015.

[8] Cutler, D. R., Edwards, T. C., Beard, K. H., Cutler, A., Hess, K. T., Gibson, J., Lawler, J. J. (2007): Random forests for classification in ecology. - Ecology 88: 2783-2792.

[9] DHI (2007): MIKE 21 Flow Model FM Hydrodynamic Module-User Guide. - Danish Hydraulic Institute, Horsholm, Denmark.

[10] Du, C., Li, Y., Wang, Q., Liu, G., Zheng, Z., Mu, M., Li, Y. (2017): Tempo-spatial dynamics of water quality and its response to river flow in estuary of Taihu Lake based on goci imagery. - Environmental Science \& Pollution Research 24(36): 1-23.

[11] Ferard, J. F., Blaise, C. (2013): Encyclopedia of aquatic ecotoxicology. - Springer Science, Dordrecht.

[12] Francke, T., López-Tarazón, J., Schroder, B. (2008): Estimation of suspended sediment concentration and yield using linear models, random forests and quantile regression forests. - Hydrological Processes 22(25): 4892-4904.

[13] Friedman, J. H. (2001): Greedy function approximation: A gradient boosting machine. Annals of Statistics 29(5): 1189-1232.

[14] Friedman, J. H., Meulman, J. J. (2010): Multiple additive regression trees with application in epidemiology. - Statistics in Medicine 22(9): 1365-1381.

[15] Gromping, U. (2009): Variable Importance Assessment in Regression: Linear Regression versus Random Forest. - The American Statistician 63(4): 308-319.

[16] Hu, W., Zhai, S., Zhu, Z., Han, H. (2008): Impacts of the Yangtze River water transfer on restoration of Lake Taihu. - Ecological Engineering 34: 30-49.

[17] Hu, C., Lee, Z., Ma, R., Yu, K., Li, D., Shang, S. (2010): Moderate resolution imaging spectroradiometer (MODIS) observations of cyanobacteria blooms in Taihu Lake, China. - Journal of Geophysical Research - Oceans 2010: 261-263.

[18] Jöbgen, A., Palm, A., Melkonian, M. (2004): Phosphorus removal from eutrophic lakes using periphyton on submerged artificial substrata. - J Lake Sci 528(1-3): 123-142. 
[19] Juma, D. W., Wang, H., Li, F. (2014): Impacts of population growth and economic development on water quality of a lake: case study of Lake Victoria Kenya water. Environ Sci Pollut R 21: 5737-5746.

[20] Kaminska, J. A. (2019): A random forest partition model for predicting $\mathrm{NO}_{2}$ concentrations from traffic flow and meteorological conditions. - Science of the Total Environment 651: 475-483.

[21] Khan, S., Ullah, R., Khan, A., Sohail, A., Wahab, N., Bilal, M., Ahmed, M. (2017): Random Forest-Based Evaluation of Raman Spectroscopy for Dengue Fever Analysis. Applied Spectroscopy 71(9): 2111.

[22] Lake Taihu Basin Authority (2012): Lake Taihu Basin and Southeast Rivers Water Resource Bulletin. - Lake Taihu Basin Authority, Shanghai.

[23] Lewis, W. M., Wurtsbaugh, W. A. (2008): Control of lacustrine phytoplankton by nutrients: Erosion of the phosphorus paradigm. - International Review of Hydrobiology 93(4-5): 446-65.

[24] Lewis, W. M., Wurtsbaugh, W. A., Paerl, H. W. (2011): Rationale for control of anthropogenic nitrogen and phosphorus to reduce eutrophication of inland waters. Environmental Science \& Technology 45(24): 10300-10305.

[25] Li, Y., Acharya, K., Stone, M. C., Yu, Z., Young, M. H., Shafer, D. S., Zhu, J., Gray, K., Stone, A., Fan, L., Tang, C. (2011a): Spatiotemporal patterns in nutrient loads, nutrient concentrations, and algal biomass in lake Taihu, china. - Lake \& Reservoir Management 27(4): 298-309.

[26] Li, Y., Acharya, K., Yu, Z. (2011b): Modeling impacts of yangtze river water transfer on water ages in Lake Taihu, China. - Ecological Engineering 37(2): 325-334.

[27] Li, Y., Tang, C., Wang, C., Anim, D. O., Yu, Z., Acharya, K. (2013): Improved yangtze river diversions: are they helping to solve algal bloom problems in Lake Taihu, China? Ecological Engineering 51(1): 104-116.

[28] Li, W., Yang, M., Liang, Z., Zhu, Y., Mao, W., Shi, J., Chen, Y. (2013): Assessment for surface water quality in Lake Taihu Tiaoxi River Basin China based on support vector machine. - Stochastic Environmental Research \& Risk Assessment 27: 1861-70.

[29] Li, A., aus der Beek, T., Schubert, M., Yu, Z., Schiedek, T., Schüth, C. (2019): Sedimentary archive of Polycyclic Aromatic Hydrocarbons andperylene sources in the northern part of Taihu Lake, China. - Environmental Pollution 246: 198-206.

[30] Liang, T., Wang, S., Cao, H., Zhang, C., Li, H., Li, H., Song, W., Chong, Z. (2008): Estimation of ammonia nitrogen load from nonpoint sources in the xitiao river catchment, China. - Journal of Environmental Sciences 20(10): 1195-1201.

[31] Liu, Y., Engel, B. A., Collingsworth, P. D., Pijanowski, B. C. (2017): Optimal implementation of green infrastructure practices to minimize influences of land use change and climate change on hydrology and water quality: Case study in Spy Run Creek watershed, Indiana. - Science of the Total Environment 601: 1400-11.

[32] Lou, J., Schwab, D. J., Beletsky, D., Hawley, N. (2000): A model of sediment resuspension and transport dynamics in southern Lake Michigan. - Journal of Geophysical Research 105(C3): 6591-6610.

[33] Maraqa, M. A., Ali, A., Khan, N. (2007): Modeling selected water quality parameters at Jebel Ali Harbour, Dubai- UAE. - Journal of Coastal Research 50: 794-799.

[34] Marttila, H., Karjalainen, S. M., Kuoppala, M., Nieminen, M. L., Ronkanen, A. K. (2018): Elevated nutrient concentrations in headwaters affected by drained peatland. - Science of the Total Environment 643: 1304-1313.

[35] Min, J. H., Wise, W. R. (2010): Depth-averaged, spatially distributed flow dynamic and solute transport modelling of a large-scaled, subtropical constructed wetland. Hydrological Processes 24(19): 2724-2737.

[36] Minnesota Pollution Control Agency (MPCA) (2006): Lake Pepin Watershed TMDL eutrophication and turbidity impairments project overview. - Minnesota. 
[37] Morton, S. C., Glindemann, D., Edwards, M. A. (2003): Phosphates, Phosphites, and Phosphides in Environmental Samples. - Environmental Science \& Technology 37: 1169-74.

[38] Muthukrishnan, R., Sleith, R. S., Karol, K. G., Larkin, D. J. (2018): Prediction of starry stonewort (Nitellopsis obtusa) invasion risk in upper Midwest (USA) lakes using ecological niche models. - Acquatic Botany 151: 43-50.

[39] Niu, X., Geng, J., Wang, X., Wang, C., Gu, X., Edwards, M., Glindemann, D. (2004): Temporal and spatial distributions of phosphine in Taihu Lake, China. - Acta Scientiae Circumstantiae 323: 169-78.

[40] Nixon, S. W. (1995): Coastal marine eutrophication: a definition, social causes, and future concerns. - Ophelia 41(1): 199-219.

[41] Nõges, P., Kägu, M., Nõges, T. (2007): Role of climate and agricultural practice in determining matter discharge into large, shallow Lake Võrtsjärv, Estonia. Hydrobiologia 581(1): 125-134.

[42] Paerl, H. W. (2009): Controlling eutrophication along the freshwater-marine continuum: dual nutrient (Nand P) reductions are essential. - Estuaries \& Coasts 32(4): 593-601.

[43] Paerl, H. W., Xu, H., McCarthy, M. J., Zhu, G., Qin, B., Li, Y., Gardner, W. S. (2011): Controlling harmful cyanobacterial blooms in a hyper-eutrophic lake (LakeTaihu, China): the need for a dual nutrient (N \& P) management strategy. - Water Res 45(5): 1973-1983.

[44] Paerl, H. W., Xu, H., Hall, N. S., Zhu, G., Qin, B., Wu, Y., Rossignol, K. L., Dong, L., McCarthy, M. J., Joyner, A. R. (2014): Controlling cyanobacterial blooms inhypertrophic Lake Taihu, China: will nitrogen reductions cause replacement ofnon-N2 fixing by N2 fixing taxa? - PLoS One 9(11):113-123.

[45] Paliwal, R., Patra, R. R. (2011): Applicability of MIKE 21 to assess temporal and spatial variation in water quality of an estuary under the impact of effluent from an industrial estate. - Water Science \& Technology 63(9): 1932-1943.

[46] Peters, J., Verhoest, N. E. C., Samson, R., Boeckx, P., Baets, B. D. (2008): Wetland vegetation distribution modelling for the identification of constraining environmental variables. - Landscape Ecology 23(9): 1049-1065.

[47] Qin, B., Xu, P., Wu, Q., Luo, L., Zhang, Y. (2007): Environmental issues of Lake Taihu, China. - Hydrobiologia 581(1): 3-14.

[48] Qin, B. (2008): Lake Taihu, China: dynamics and environmrntal change. - Spring Science \& Business Media.

[49] Qin, B., Zhu, G., Gao, G., Zhang, Y., Li, W., Paerl, H. W., Carmichael, W. W. (2010): Adrinking water crisis in Lake Taihu, China linkage to climatic variability and lake management. - Environ Manage 4: 105-112.

[50] Qin, B., Gao, G., Zhu, G. W. (2013): Lake eutrophication and its ecosystem response. Chinese Science Bulletin 58(9): 961-970.

[51] Qin, B., Li, W., Zhu, G., Zhang, Y., Wu, T., Gao, G. (2015): Cyanobacterial bloom management through integrated monitoring and forecasting in large shallow eutrophic lake Taihu (china). - Journal of Hazardous Materials 287(2): 356-363.

[52] Rao, Y. R., Schwab, D. J. (2007): Transport and mixing between the coastal and offshore waters in the great lakes: a review. - J Great Lakes Res 33: 202-218.

[53] Rasmussen, E. K., Petersen, O. S., Thompson, J. R., Flower, R. J., Ahmed, M. H. (2009): Hydrodynamic-ecological model analyses of the water quality of Lake Manzala. Hydrobiologia 622(1): 195-220.

[54] Rodriguez-Galiano, V., Sanchez-Castillo, M., Chica-Olmo, M., Chica-Rivas, M. (2015): Machine learning predictive models for mineral prospectivity: An evaluation of neural networks, random forest, regression trees and support vector machines. - Ore Geology Reviews 71: 804-818.

[55] Schindler, D. W. (2006): Recent advances in the understanding and management of eutrophication. - Limnology \& Oceanography 51: 356-63. 
[56] Schindler, D. W., Vallentyne, J. R. (2008): The Algal Bowl: Overfertilization of the World's Freshwaters and Estuaries. - University of Alberta Press, Edmonton.

[57] Schindler, D. W., Hecky, R. E. (2009): Eutrophication: more nitrogen data needed. Science 324: 721-722.

[58] Suttle, C. A., Harrison, P. J. (2010): Rapid ammonium uptake by freshwater phytoplankton. - Journal of Phycology 24(1): 13-16.

[59] Tang, C., Li, Y., Acharya, K. (2016): Modeling the effects of external nutrient reductions on algal blooms in hyper-eutrophic Lake Taihu, China. - Ecological Engineering 94: 164173.

[60] Tao., Y., Yao, S., Xue, B., Deng, J., Wang, X., Feng, M., Hu, W. (2010): Polycyclic aromatichydrocarbons in surface sediments from drinking water sources of Taihu Lake, China: sources, partitioning and toxicological risk. - J Environ Monit 12: 2282-2289.

[61] United States Environmental Protection Agency (USEPA) (2000): Nutrient criteria technical guidance manual: lakes and reservoirs, Report no. EPA-822-B00-001. Washington DC.

[62] United States Environmental Protection Agency (USEPA) (2013): Surface water quality standards. - Washington DC.

[63] Wang, S. H., Huggins, D. G., Frees, L., Volkman, C. G., Lim, N. C., Baker, D. S. (2005): An Integrated Modeling Approach to Total Watershed Management: Water Quality and Watershed Assessment of Cheney Reservoir, Kansas, USA. - Water Air and Soil Pollution 164(1-4): 1-19.

[64] Wang, M., Shi, W., Tang, J. (2011): Water property monitoring and assessment for china's inland lake taihu from modis-aqua measurements. - Remote Sensing of Environment 115(3): 841-854.

[65] Wang, J., Fu, Z., Qiao, H. (2019): Assessment of eutrophication and water quality in the estuarine area of Lake Wuli, Lake Taihu, China. - Science of The Total Environment 650: 1392-1402.

[66] Were, K., Bui, D. T., Dick, O. B., Singh, B. R. (2015): A comparative assessment of support vector regression, artificial neural networks, and random forests for predicting and mapping soil organic carbon stocks across an Afromontane landscape. - Ecological Indicators 52: 394-403.

[67] Wisconsin Department of Nature Resources (WDNR) (2004): Phosphorus Total Maximum Daily Load (TMDL) for Half Moon Lake. - Eau Claire, Wisconsin.

[68] Wu, P., Qin, B., Yu, G., Deng, J., Zhou, J. (2016): Effects of nutrient on algae biomass during summer and winter in inflow rivers of Taihu Basin, China. - Water Environment Research 88: 665-672.

[69] Xu, H., Paerl, H. W., Qin, B., Zhu, G., Gao, G. (2010): Nitrogen and phosphorus inputs control phytoplankton growth in eutrophic Lake Taihu, China. - Limnology \& Oceanography 55(1): 420-432.

[70] Xu, H., Paerl, H. W., Qin, B., Zhu, G., Hall, N. S., Wu, Y. (2015): Determining critical nutrient thresholds needed to control harmful cyanobacterial blooms in eutrophic Lake Taihu, China. - Environmental Science \& Technology 49(2): 1051-1059.

[71] Ye, S., Chen, X., Dong, D., Wang, J., Wang, X., Wang, F. (2018): Rapid determination of water cod using laser-induced breakdown spectroscopy coupled with partial least-squares and random forest. - Analytical Methods 40(10): 4879-4885.

[72] Zhang, X., Chen, Q. (2011): Spatial-temporal characteristic of water quality in Lake Taihu and its relationship with algal bloom. - Journal of Lake Sciences 23: 339-47.

[73] Zhang, Y., Shi, K., Liu, X., Zhou, Y., Qin, B. (2014): Lake topography and wind waves determining seasonal-spatial dynamics of total suspended matter in turbid Lake Taihu, China: assessment using long-term high-resolution MERIS data. - Plos One 9(5): 98055.

[74] Zhang, Y., Shi, K., Zhou, Y., Liu, X., Qin, B. (2016): Monitoring the river plume induced by heavy rainfall events in large, shallow, Lake Taihu using MODIS 250m imagery. Remote Sensing of Environment 173: 109-121. 
[75] Zhang, T., Ban, X., Wang, X., Cai, X., Li, E., Wang, Z. (2017): Analysis of nutrient transport and ecological response in honghu lake, china by using a mathematical model. Science of the Total Environment 575: 418-428.

[76] Zhu, C., Liang, Q., Yan, F., Hao, W. (2013): Reduction of waste water in Erhai Lake based on MIKE21 hydrodynamic and water quality model. - The scientific world journal 5: 958506. 